Article

\title{
Critical Point Drying: An Effective Drying Method for Direct Measurement of the Surface Area of a Pretreated Cellulosic Biomass
}

\author{
Kyu-Young Kang ${ }^{1}$, Kyung-Ran Hwang ${ }^{2}$, Ji-Yeon Park ${ }^{2}$, Joon-Pyo Lee ${ }^{3}$, Jun-Seok Kim ${ }^{4}$ and \\ Jin-Suk Lee ${ }^{3, *}$ \\ 1 Department of Biological and Environmental Science, Dongguk University-Seoul, 32 Dongguk-ro, \\ Ilsandong-gu, Goyang 10326, Korea; kykang@dongguk.edu \\ 2 Biomass and Waste Energy Laboratory, Korea Institute of Energy Research, 152 Gajeong-ro, Yuseong-gu, \\ Daejeon 34129, Korea; hkran@kier.re.kr (K.-R.H.); yearn@kier.re.kr (J.-Y.P.) \\ 3 Gwangju Bioenergy R\&D Center, Korea Institute of Energy Research, 25 Samso-ro270beongil, Buk-gu, \\ Gwangju 61003, Korea; bmjplee@kier.re.kr \\ 4 Department of Chemical Engineering, Kyonggi University, 154-42 Gwanggyosan-ro, Yeongtong-gu, \\ Suwon 16227, Korea; jskim84@kyonggi.ac.kr \\ * Correspondence: bmjslee@kier.re.kr; Tel.: +82-62-717-2410
}

Received: 24 May 2018; Accepted: 14 June 2018; Published: 17 June 2018

\begin{abstract}
The surface area and pore size distribution of Eucalyptus samples that were pretreated by different methods were determined by the Brunauer-Emmett-Teller (BET) technique. Three methods were applied to prepare cellulosic biomass samples for the BET measurements, air, freeze, and critical point drying (CPD). The air and freeze drying caused a severe collapse of the biomass pore structures, but the CPD effectively preserved the biomass morphology. The surface area of the CPD prepared Eucalyptus samples were determined to be $58-161 \mathrm{~m}^{2} / \mathrm{g}$, whereas the air and freeze dried samples were $0.5-1.3$ and $1.0-2.4 \mathrm{~m}^{2} / \mathrm{g}$, respectively. The average pore diameter of the CPD prepared Eucalyptus samples were 61-70 A. The CPD preserved the Eucalyptus sample morphology by replacing water with a non-polar solvent, $\mathrm{CO}_{2}$ fluid, which prevented hydrogen bond reformation in the cellulose.
\end{abstract}

Keywords: pretreated cellulosic biomass; critical point drying; surface area; pore size distribution; Brunauer-Emmett-Teller (BET); cellulose; hornification

\section{Introduction}

For the efficient sugar fractionation from the lignocellulosic biomass, physical contact between cellulose and cellulase enzymes is necessary. Therefore, the cellulose specific surface area that is available for enzyme contact is one of the most important factors for determining the rate and extent of the enzymatic hydrolysis of the biomass [1-3]. Since the average size of cellulase enzymes is approximately $5.1 \mathrm{~nm}$, the internal surface of the pores that are greater than $5.1 \mathrm{~nm}$ should be particularly effective for enzymatic hydrolysis [4]. Various pretreatments that have been applied for the improved enzymatic digestibility also increase the surface area, as a result of not only the removal of hemicellulose and/or lignin, but also cellulose swelling. Most studies regarding the biomass specific surface area and pore size distribution have employed indirect measurement techniques, such as solute exclusion [5-8], non-hydrolytic protein adsorption [9], Simons' staining [10-12], and NMR techniques $[13,14]$.

Solute exclusion is the most widely employed method, but it has several drawbacks, including a relatively low accuracy and limitations on the pore size ranges that can be determined. For example, 
given the unavailability of dextran molecule probes, only pore sizes up to $56 \mathrm{~nm}$ can be measured [5-7,15]. However, the non-ionic surfactant pretreatment of the lignocellulosic biomass can produce pores with up to a $100 \mathrm{~nm}$ diameter [16]. Inaccurate estimation can also arise from the water competition with the solute probes [1] and/or solute concentration measurement errors. The reported biomass surface area varies greatly, from 20 to over $1500 \mathrm{~m}^{2} / \mathrm{g}[7,15]$.

The Simons' staining method has also been used to determine the feasibility of the enzymatic hydrolysis of substrates [10-12,17], although this technique can provide only semi-quantitative information. It also has similar limitations to the solute exclusion, since it also employs dye solutes for the measurement. On the other hand, the NMR techniques that have been employed for the biomass surface area measurement require complicated experiment set-ups [13,14].

The Brunauer-Emmett-Teller (BET) technique employing $\mathrm{N}_{2}$ adsorption has many advantages, including a high accuracy, and it can measure $0.4-300 \mathrm{~nm}$ pore sizes [18]. Therefore, the BET technique is widely used to determine the surface area and pore size distribution of porous materials, although it is applicable only to dried samples. Few studies have considered the BET based internal surface area measurement of the pretreated biomass $[11,19,20]$. However, these have indicated that the BET measured surface areas differ significantly from those that have been measured by other methods, (i.e., solute exclusion, dye staining, or probes). For example, Wiman et al. compared a steam pretreated spruce surface area using the BET and Simons' staining methods [11]. The BET measurement biomass samples were oven dried at $30^{\circ} \mathrm{C}$ for $24 \mathrm{~h}$ to minimize structural changes. The pretreated biomass surface area was $1.3-8.2 \mathrm{~m}^{2} / \mathrm{g}$, far smaller than those that were measured by the staining method (53-64 $\mathrm{m}^{2} / \mathrm{g}$ ). The small BET based surface area was attributed mainly to the pore collapse during air drying [12,21].

To avoid a pore collapse, freeze drying has been applied to cellulose and yellow poplar (Liriodendron tulipifera) wood flour, which has been pretreated by the organosolv process $[19,20]$, but the biomass surface area remains small, 5-39 and $1.8 \mathrm{~m}^{2} / \mathrm{g}$ for thecellulose and organosolv pretreated yellow poplar, respectively. Esteghalian et al. investigated the effects of the drying conditions on the enzymatic hydrolysis of Douglas fir (Pseudotsuga menziesii) kraft pulp using air, oven, and freeze drying; and compared the dried biomass enzymatic digestibilities. No significant differences between the air and freeze dried biomass samples were evident [17]. Thus, no successful method remains that prevents pore collapse when drying the cellulosic biomass. Therefore, the cellulosic biomass surface area is mainly determined by in situ measuring techniques.

Critical point drying (CPD) is widely used to dry delicate samples for scanning electron microscope (SEM) applications and could be a viable option for biomass sample preparation, while maintaining the original morphology. Since pore collapse is caused by the removal of water (a polar solvent) from the biomass [12,21], this study attempted to prevent pore collapse by replacing water with non-polar solvents before drying. Since CPD employing a non-polar solvent (liquid $\mathrm{CO}_{2}$ ) is done at $\sim 36{ }^{\circ} \mathrm{C}$, deterioration that is caused by a high drying temperature can be minimized. There have been no previous reports on the direct measurement of the surface area and/or pore size distribution for the CPD pretreated cellulosic biomass.

This study prepared Eucalyptus wood flour samples using three pretreatment methods to measure the total surface area and pore size distribution, and the drying conditions' effects on the surface area and pore size distribution were compared. This work will contribute to a deeper understanding of the physical effects of surface area and pore size distribution on enzymatic hydrolysis rates of cellulosic biomass.

\section{Materials and Methods}

\subsection{Materials}

The Eucalyptus (E. grandis) wood chips were supplied by Dr. Zhuang of the GuangZhou Institute of Energy Conversion, Chinese Academy of Science (GIEC) in China; knife milled by the Wiley 
mill (Mini Wiley mill, Thomas Scientific, Swedesboro, NJ, USA); and screened to a nominal size of 20-60 mesh. The alkaline electrolyzed water (ALEW) was provided by Gendocs Inc. (Daejeon, Korea) with a $\mathrm{pH}=12.2$ and $\mathrm{ORP}<-795 \mathrm{mV}$. All of the other reagents and chemicals were of an analytical grade and were purchased from either Sigma-Aldrich (St. Louis, MO, USA) or local suppliers in Korea.

\subsection{Pretreatments of Lignocellulosic Biomass}

The Eucalyptus samples as a lignocellulosic biomass were pretreated by dilute acid (DA), steamed after $\mathrm{NaOH}$ impregnation, and ALEW. For the DA pretreatment, $60 \mathrm{~g}(\mathrm{OD})$ of a biomass sample was immersed in $160 \mathrm{~mL}$ of $3 \%(w / w)$ sulfuric acid and was maintained at $121^{\circ} \mathrm{C}$ for $2 \mathrm{~h}$. The slurry was allowed to stand overnight and was then filtered (Whatman No. 1 glass filter) to recover the insoluble solids. The recovered cellulosic biomass was washed with distilled water several times. The process of $\mathrm{NaOH}$-steam pretreatment followed the procedure that was detailed previously by the authors of [22]. Then, $60 \mathrm{~g}(\mathrm{OD})$ of the biomass sample was soaked in $480 \mathrm{~mL}$ of $\mathrm{s} 3 \%(w / v)$ sodium hydroxide solution at room temperature. The slurry was allowed to stand overnight and was then filtered (Whatman No. 1 glass filter) to recover the insoluble solids. The recovered solids were transferred to an autoclave (working volume $=1 \mathrm{~L}$ ) and the steam pretreatment was conducted at $160^{\circ} \mathrm{C}$ for 12 min under a 20 bar nitrogen atmosphere. For the ALEW pretreatment, $60 \mathrm{~g}(\mathrm{OD})$ of the biomass sample was immersed in $600 \mathrm{~mL}$ ALEW and was maintained at $180^{\circ} \mathrm{C}$ for $1 \mathrm{~h}$ in an autoclave (working volume $=1 \mathrm{~L}$ ) under a 20 bar nitrogen atmosphere.

\subsection{Drying of Cellulosic Biomass Sample}

The pretreated samples were dried by air, were frozen, and by critical point drying methods. For the air drying (AD), approximately $5 \mathrm{~g}$ of each of the pretreated cellulosic biomass samples were dried in a vacuum oven at $50{ }^{\circ} \mathrm{C}$ for $48 \mathrm{~h}$. The constant weight was confirmed after drying. The freeze drying (FD) process of the cellulosic biomass sample followed that which was detailed in the literature [19]. Approximately $5 \mathrm{~g}$ of the pretreated cellulosic biomass sample was frozen at $-60{ }^{\circ} \mathrm{C}$ for $48 \mathrm{~h}$, and was then vacuumed in a FD apparatus for $72 \mathrm{~h}$. The critical point drying (CPD) was performed using a critical point dryer (13200J-AB, SPI Supplies, West Chester, PA, USA), following the procedure that was provided in the operation manual. Approximately $5 \mathrm{~g}$ of the pretreated biomass samples were placed in $100 \mathrm{~mL}$ of $30,50,70,90,95$, and $100 \%$ ethanol for $15 \mathrm{~min}$, and were then immersed in an acetone solution for a further $15 \mathrm{~min}$. After a series of the solvent exchanges, the acetone in the samples became replaced by liquid $\mathrm{CO}_{2}$, and the samples were then critical point dried at $36^{\circ} \mathrm{C}$.

\subsection{Surface Area and Pore Size Measurements of Biomass Sample}

We used the BET method to determine the surface area, average pore diameter, and total pore volume for the $\mathrm{AD}, \mathrm{FD}$, and $\mathrm{CPD}$ biomass samples. The $\mathrm{N}_{2}$ adsorption was measured using an accelerated surface area and porosity analyzer (ASAP 2420, Micromeritics Inc., Norcross, GA, USA). The $\mathrm{N}_{2}$ adsorption isotherms were obtained by measuring the amount of gas that was adsorbed across a range of relative pressures $\left(P / P_{0}\right)$ at constant temperature $\left(-196{ }^{\circ} \mathrm{C}\right.$, liquid nitrogen phase temperature), where $P$ and $P_{0}$ were the equilibrium and saturation pressures, respectively, of the adsorbate gas at the temperature of adsorption. The desorption isotherms were achieved by measuring the amount of $\mathrm{N}_{2}$ gas that was removed as the pressure decreased. Subsequently, the specific surface area was calculated from the adsorption isotherms, using the BET theory. The total pore volume was estimated from the amount of $\mathrm{N}_{2}$ gas that was adsorbed at 0.98 of the relative pressure, under the following assumptions: the pores were filled with liquid nitrogen, and adsorption average pore size was derived from $4 V / A$, where $V$ was the total pore volume, and $A$ was the surface area corresponding to the assumed cylindrical pore model. The pore size distribution was obtained from the experimental isotherms, as detailed elsewhere [23]. Prior to the BET analysis, the pre-dried samples were degassed at $90{ }^{\circ} \mathrm{C}$ for $0.5 \mathrm{~h}$, and then again at $105^{\circ} \mathrm{C}$ for $4 \mathrm{~h}$. 


\subsection{FTIR and SEM Analyses}

The structural changes of the raw and pretreated samples were examined with Fourier transform infrared spectroscopy (FTIR). The samples were ground into a powder and sieved through a $149 \mu \mathrm{m}$ mesh. The FTIR spectra were recorded on an FTS-175C (Bio-Rad Laboratories Inc., Hercules, CA, USA) that was equipped with a mercury cadmium telluride detector, using $\mathrm{KBr}$ pellets. All of the spectra were collected at a $4 \mathrm{~cm}^{-1}$ resolution, with $32 \mathrm{scans}$ in the range $4000-500 \mathrm{~cm}^{-1}$. The SEM observation was also performed to confirm the structural changes of the samples using the FE-SEM (S-4700, Hitachi, Tokyo, Japan).

\section{Results and Discussion}

\subsection{Drying Methods Effects on Surface Area and Pore Size Distribution of Pretreated Eucalyptus}

The surface area and pore size distribution of the samples were determined by BET and the differences were compared among the $\mathrm{CPD}, \mathrm{AD}$, and FD pretreatments. Figure 1 shows the $\mathrm{N}_{2}$ adsorption-desorption isotherms for ALEW, $\mathrm{DA}$, and $\mathrm{NaOH}$-steam pretreated samples. The isotherms were the typical type IV hysteresis loops (as classified by IUPAC), which were consistent with mesoporous materials, where an adsorbate monolayer was formed on the pore surface at low pressures, followed by a multilayer formation. The hysteresis loop originated from the capillary condensation in meso- and macro-pores, and could have a wide variety of shapes, depending on the pore geometries. Specific pore structures could often be identified from their hysteresis loop shape, based on the empirical IUPAC classification. The AD and FD samples also exhibited H4 type hysteresis loops, although somewhat smaller. This hysteresis type was consistent with narrow slit shaped pores and/or aggregated particles [24]. The pore collapse in the cellulose fibers was more significant during the $\mathrm{AD}$ procedure than the FD, based on their adsorbed quantity. All of the CPD samples exhibited H2 type hysteresis loops, where the pore size and pore shape distribution were difficult to interpret well. According to the literature [25-27], the H2 loop with the steeper desorption slope than the adsorption slope occurred in the network of the ink-bottle pores. This meant that the cellulose fibers cell walls were partially collapsed and then the narrow pore necks and the wide pore body were interconnected during the CPD procedure.

Figure 2 shows the corresponding biomass pore size distribution, which was determined by the $\mathrm{BJH}$ (Barrett-Joyner-Halenda) method. As reported elsewhere, the AD and FD samples' large pores indicated a collapse of most of the small pore structures during drying [25]. However, the CPD showed distinguishable pore volume and appeared to maintain the pore structures in the pretreated Eucalyptus samples, with the average pore size of approximately $6.2 \mathrm{~nm}$ (i.e., within the mesopore range).

Table 1 shows the detailed quantitative data for the ALEW pretreated Eucalyptus samples. The surface area of the pretreated Eucalyptus samples varied greatly with the drying conditions. The smallest surface areas were from the AD samples $\left(0.5-1.3 \mathrm{~m}^{2} / \mathrm{g}\right)$, with the FD samples having approximately twice the area $\left(1.04-2.44 \mathrm{~m}^{2} / \mathrm{g}\right)$, although they had comparable small pore volumes (0.002-0.005 and $0.005-0.015 \mathrm{~cm}^{3} / \mathrm{g}$, respectively); whereas the CPD samples' surface area and pore volume were considerably larger (58.5-161.5 $\mathrm{m}^{2} / \mathrm{g}$ and $0.103-0.249 \mathrm{~cm}^{3} / \mathrm{g}$, respectively). The structural changes of the ALEW pretreated Eucalyptus samples, according to the different drying methods, were confirmed by the SEM observation, as shown in Figure 3. From the results of the SEM observations, it was obvious that the CPD method preserved the microstructure and was effective in the drying of the pretreated cellulosic biomass samples. It was a similar result to the study on the application of the CPD for the accurate surface area measurement of the other samples [28]. 

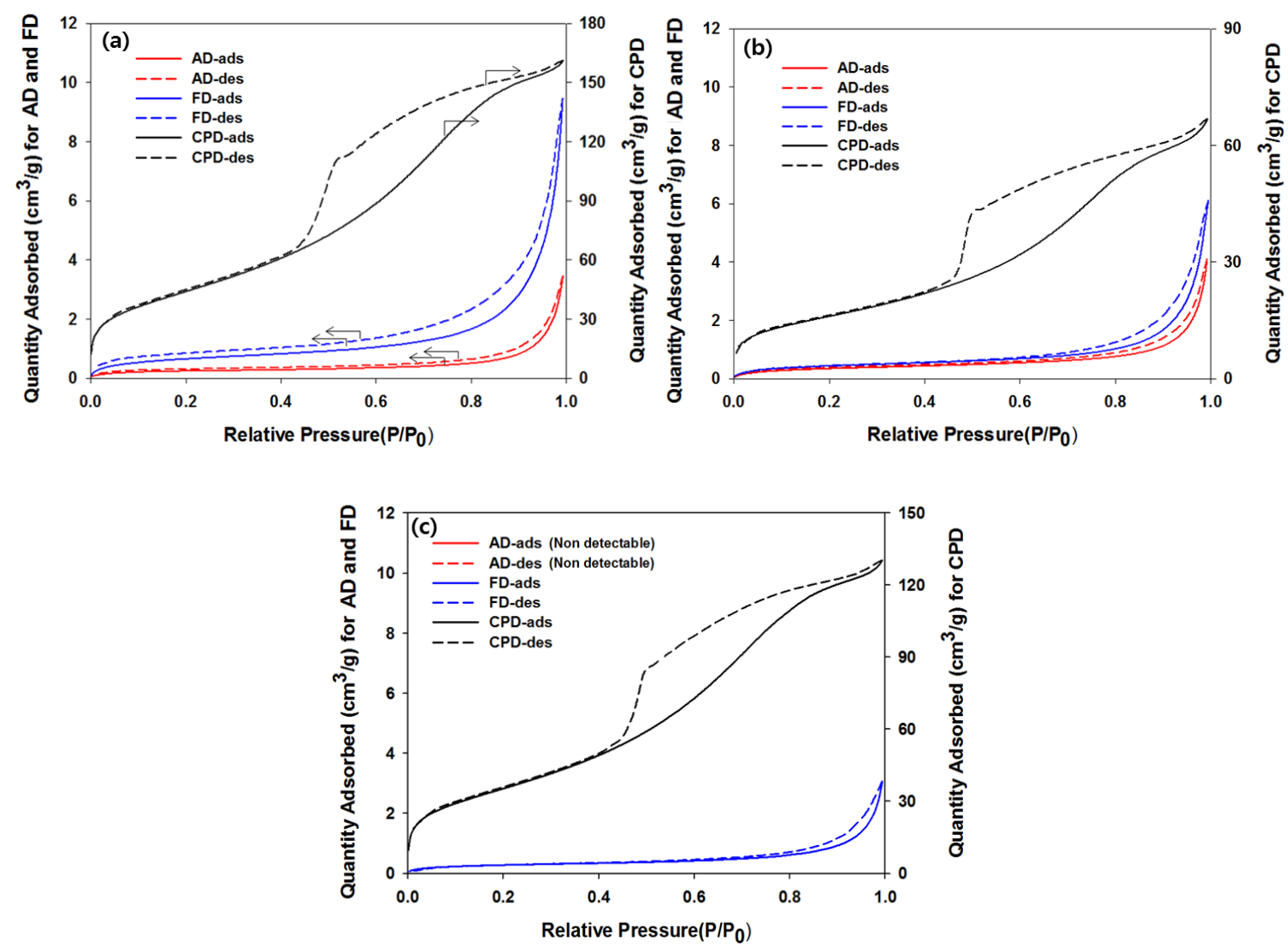

Figure 1. Nitrogen adsorption-desorption isotherms for air (AD), freeze (FD), and critical point (CPD) dried Eucalyptus samples with (a) ALEW, (b) $1 \% \mathrm{H}_{2} \mathrm{SO}_{4}$, and (c) $\mathrm{NaOH}$-steam pretreatments.

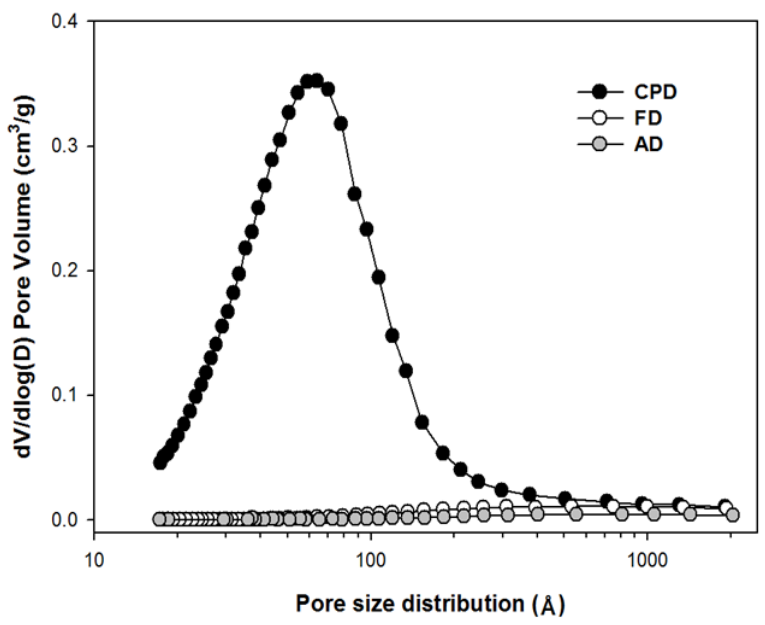

Figure 2. Drying method effects on pore size distribution for alkaline electrolyzed water (ALEW) pretreated Eucalyptus samples.

As shown in Table 2, the surface area of the AD Eucalyptus samples was somewhat smaller than what was previously reported for $\mathrm{SO}_{2}$-steam pretreated spruce $\left(1.3-8.2 \mathrm{~m}^{2} / \mathrm{g}\right)$ [11], which was possibly because of the different feedstocks and pretreatment conditions. However, the surface area of the $\mathrm{SO}_{2}$-steam pretreated spruce varied greatly with the pretreatment conditions that were tested in that study. The surface area of the FD Eucalyptus samples was comparable to that which was previously 
reported for the yellow poplar (L. tulipifera) $\left(1.80 \mathrm{~m}^{2} / \mathrm{g}\right)$ and were prepared by FD after the organosolv pretreatment [20]. Table 3 compares the surface areas of the CPD Eucalyptus samples with those that were previously reported. The CPD surface area for the DA pretreated Eucalyptus $\left(57.3 \mathrm{~m}^{2} / \mathrm{g}\right) \mathrm{was}$ very close to the $\mathrm{SO}_{2}$-steam pretreated spruce that was determined by dye staining $\left(58.5 \mathrm{~m}^{2} / \mathrm{g}\right)$ [11].

Thus, only the CPD effectively maintained the pretreated biomass morphology, although both of the FD and CPD were previously reported as effective. Both of the drying methods were widely employed in the SEM specimen preparation [29]. The poor performance of the FD for the water-swollen lignocellulose that were reported here was probably associated with the cellulose content of the feedstock, since the cellulose was deformed by hornification, a consequence of the irreversible changes to the cell wall structure [12].

Table 1. Mean surface areas, pore diameters, and total pore volumes for the alkaline electrolyzed water (ALEW) pretreated Eucalyptus samples.

\begin{tabular}{|c|c|c|c|c|}
\hline Pretreatment & Drying Method & Surface Area $\left(\mathrm{m}^{2} / \mathrm{g}\right)$ & $\begin{array}{l}\text { Average Pore } \\
\text { Diameter (Å) }\end{array}$ & $\begin{array}{c}\text { Total Pore Volume } \\
\left(\mathrm{cm}^{3} / \mathrm{g}\right)\end{array}$ \\
\hline \multirow{3}{*}{ ALEW } & $\mathrm{AD}^{1}$ & 0.9 & - & 0.005 \\
\hline & $\mathrm{FD}^{2}$ & 2.4 & - & 0.015 \\
\hline & $\mathrm{CPD}^{3}$ & 161.5 & 61.7 & 0.249 \\
\hline
\end{tabular}

${ }^{1}$ Air drying. ${ }^{2}$ Freeze drying. ${ }^{3}$ Critical point drying.
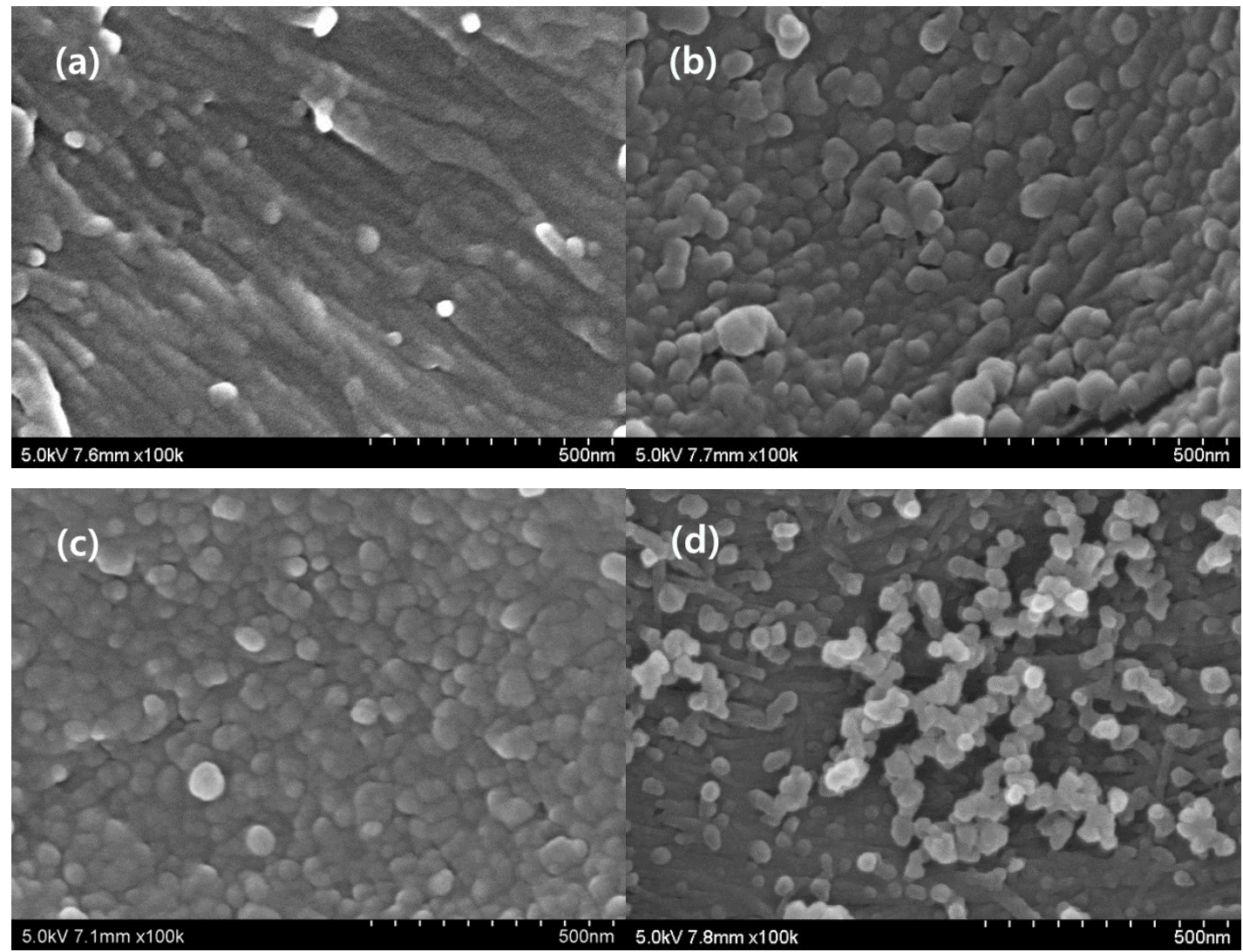

Figure 3. SEM images of the ALEW pretreated Eucalyptus samples, according to the different drying methods, namely: the (a) untreated control, (b) air drying (AD), (c) freeze drying (FD), and (d) critical point drying (CPD). 
Table 2. Drying method effect on the Brunauer-Emmett-Teller (BET) surface area.

\begin{tabular}{cccc}
\hline Biomass & Drying Condition & Surface Area $\left(\mathbf{m}^{2} / \mathbf{g}\right)$ & Reference \\
\hline Spruce $^{1}$ & Air drying at $30{ }^{\circ} \mathrm{C}$ & 6.3 & {$[11]$} \\
Yellow poplar $^{2}$ & Freeze drying & 1.8 & {$[20]$} \\
Eucalyptus $^{3}$ & Critical point drying & 58.5 & Current paper \\
\hline
\end{tabular}

${ }^{1}$ Pretreated by $2.5 \% \mathrm{SO}_{2}$ at $207{ }^{\circ} \mathrm{C}$ for $7 \mathrm{~min} .{ }^{2}$ Pretreated by EtOH (organosolv) at $130{ }^{\circ} \mathrm{C}$ for $50 \mathrm{~min} .{ }^{3}$ Pretreated by $1 \% \mathrm{H}_{2} \mathrm{SO}_{4}$ at $121^{\circ} \mathrm{C}$ for $2 \mathrm{~h}$.

Although the exact hornification mechanism was unclear, one possible explanation was the hydrogen bond breaking and reforming, corresponding to the cellulose wetting and drying, respectively. When the cellulose was wet, the fibers swelled by the hydrogen bond breakage, but shrunk with the reforming of the hydrogen bonds upon drying. In any case, the reason for the poor FD performance remained unknown. Possibly FD removed only free water, but not the bound water, inducing the cellulosic collapse [30]. However, hydrogen reforming could be prevented if the bound water in the pretreated Eucalyptus samples was replaced by a non-polar solvent prior to drying. To examine this hypothesis, we performed an FTIR analysis to examine the hydrogen bonds in the ALEW pretreated AD and CPD Eucalyptus samples, as shown in Figure 4.

The O-H alcohol stretching region of the FTIR absorbance band, $4000-3000 \mathrm{~cm}^{-1}$, was reported to contain the information on hydrogen bonding in cellulose [31,32], and large peaks were observed between $3390-3340 \mathrm{~cm}^{-1}$. The ALEW pretreated CPD Eucalyptus sample peaks were significantly smaller than those of the untreated and ALEW pretreated AD Eucalyptus. The AD Eucalyptus peak height was very similar to that of the untreated Eucalyptus. Thus, since the peak height was proportional to the hydrogen bonds in the biomass sample, the CPD Eucalyptus had significantly fewer hydrogen bonds than the untreated or AD Eucalyptus. The peaks at $1739.8 \mathrm{~cm}^{-1}$ and between $1260-1234 \mathrm{~cm}^{-1}$ indicated $\mathrm{C}=\mathrm{O}$ carbonyls and $\mathrm{O}-\mathrm{H}$ phenolic, respectively, and these peaks were getting smaller by drying. Overall, the hydrogen bonds in the untreated Eucalyptus were broken by water during the pretreatment and were subsequently reconnected upon the AD. However, the hydrogen bond reformation upon drying was successfully prevented for the CPD Eucalyptus samples, replacing the bound water with a non-polar solvent (liquid $\mathrm{CO}_{2}$ ), prior to drying. Finally, the wide peak at $3388.9 \mathrm{~cm}^{-1}$ shifted to s higher frequency after the drying of the ALEW pretreated Eucalyptus. This shift was more significant with the $\mathrm{AD}$, where the hydrogen bonding became stronger than what was the case for the untreated sample.

Table 3. Comparison of the BET results with those that were determined by non-drying measurement techniques.

\begin{tabular}{|c|c|c|c|c|}
\hline Biomass & $\begin{array}{l}\text { Measurement } \\
\text { Technique }\end{array}$ & $\begin{array}{l}\text { Surface Area } \\
\left(\mathrm{m}^{2} / \mathrm{g}\right)\end{array}$ & $\begin{array}{l}\text { Surface Area Accessible } \\
\text { to Cellulose }\left(\mathrm{m}^{2} / \mathrm{g}\right)\end{array}$ & Reference \\
\hline \multirow{2}{*}{ Corn cob } & Solute exclusion & - & $\begin{array}{l}57.4^{1} \\
34.1^{2}\end{array}$ & [7] \\
\hline & Protein adsorption & - & $7.7^{3}$ & [33] \\
\hline Lodgepole pine pulp 4 & Solute exclusion & - & 22.4 & [8] \\
\hline Mixed hard wood ${ }^{5}$ & Solute exclusion & 1134 & 25.8 & [15] \\
\hline Filter paper & Protein adsorption & - & 9.8 & [9] \\
\hline Spruce 6 & Dye staining & 57.3 & - & [11] \\
\hline Eucalyptus ${ }^{7}$ & BET & 58.5 & - & Current paper \\
\hline
\end{tabular}

${ }^{1}$ Pretreated by $2 \% \mathrm{NaOH}$ at $80{ }^{\circ} \mathrm{C}$ for $6 \mathrm{~h} .{ }^{2}$ Pretreated by $2 \% \mathrm{H}_{2} \mathrm{SO}_{4}$ at $120{ }^{\circ} \mathrm{C}$ for $0.75 \mathrm{~h} .{ }^{3}$ Pretreated by $0.048 \mathrm{~g}$ $\mathrm{H}_{2} \mathrm{SO}_{4} / \mathrm{g}$ biomass at $190{ }^{\circ} \mathrm{C}$ for $1 \mathrm{~min} .{ }^{4}$ Pretreated by SPORL at $180{ }^{\circ} \mathrm{C}$ for $20 \mathrm{~min} .{ }^{5}$ Pretreated by $1 \% \mathrm{H}_{2} \mathrm{SO}_{4}$ at $180{ }^{\circ} \mathrm{C}$ for $8.3 \mathrm{~s} .{ }^{6}$ Pretreated by $2.5 \% \mathrm{SO}_{2}$ at $207^{\circ} \mathrm{C}$ for $7 \mathrm{~min} .{ }^{7}$ Pretreated by $1 \% \mathrm{H}_{2} \mathrm{SO}_{4}$ at $121{ }^{\circ} \mathrm{C}$ for $2 \mathrm{~h}$. 


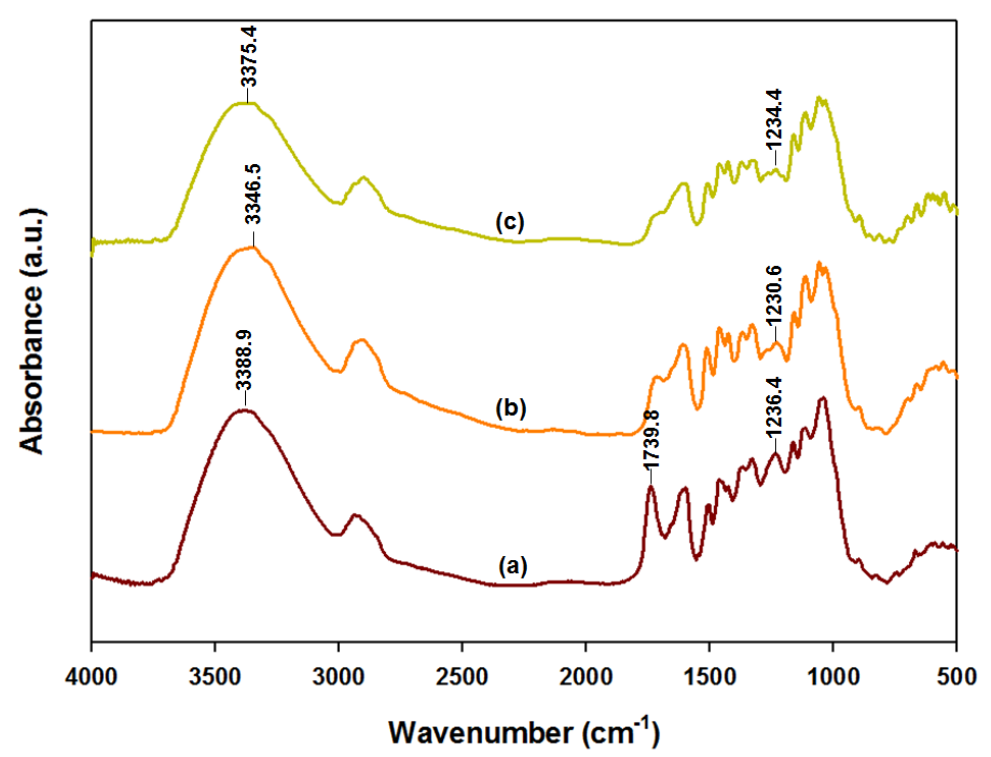

Figure 4. FTIR spectra for the dried Eucalyptus samples, before and after ALEW, as follows: (a) untreated control, (b) air drying (AD) after ALEW, and (c) critical point drying (CPD) after ALEW.

\subsection{Pretreatment Conditions Effects on Surface Area and Pore Size Distribution}

Since the pore volumes varied sharply with the pretreatment methods (Figure 5), we investigated the pretreatment condition influences on the pore volumes, surface area, and pore size distribution for the CPD Eucalyptus samples. The alkali pretreatment yielded a biomass with a higher pore volume and surface area than those that were achieved by the acid pretreatment. The swelling effects of the alkali pretreatment have been reported previously. Huang et al. showed that $\mathrm{NaOH}$ pretreated corn cob had an approximately $40 \%$ larger surface area $\left(57.4 \mathrm{~m}^{2} / \mathrm{g}\right)$ than the corresponding sulfuric acid pretreated sample [7]. In the current study, the ALEW pretreatment exhibited the strongest swelling effect on the Eucalyptus samples, with an approximately $20 \%$ higher pore volume but similar average pore size, hence, an approximately $20 \%$ larger surface area than the $\mathrm{NaOH}-$ steam pretreatment.

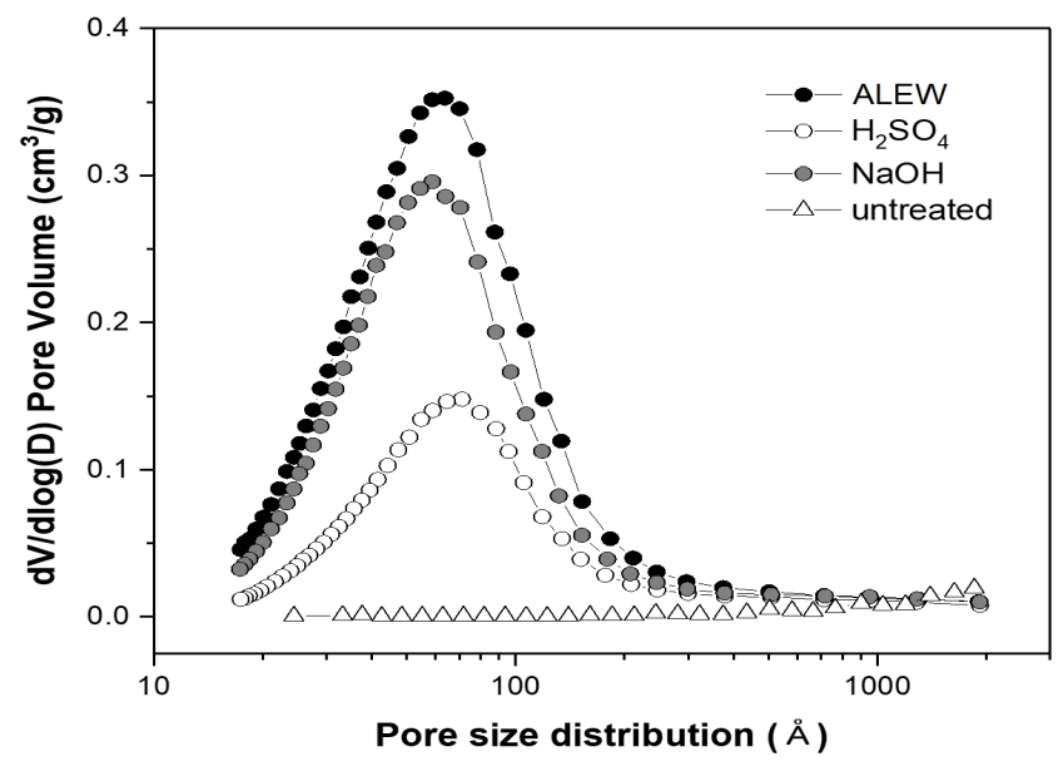

Figure 5. Pretreatment method effects on the pore size distribution for the ALEW critical point dried Eucalyptus samples. 
Table 4 summarizes the effects of these and the other quantified pretreatments on the pore volume and surface area of the Eucalyptus samples. The DA pretreatment exhibited the lowest pore volume and the smallest surface area, approximately $45 \%$ of the values from the $\mathrm{NaOH}$ pretreated Eucalyptus samples. The reason for the smaller surface area with the DA pretreatment was unclear, although it was likely because of cellulose aggregation. Changes in the chemical composition could also be another possible reason, as the removal of the lignin and hemicellulose had a significant effect on the surface area and pore size distribution [7].

The biomass pore volume and surface area provided the enzymes with sufficient access and adsorption to the cell surfaces, thus significantly affecting the enzymatic hydrolysis of the cellulose. Therefore, we determined the pore volumes for the different pore sizes, as shown in Table 5. The ALEW pretreated Eucalyptus samples exhibited the largest pore volume accessible to the enzymes, with the $\mathrm{NaOH}$ pretreated samples exhibiting the highest pore volumes for the pores that were smaller than $2 \mathrm{~nm}$, and the ALEW pretreated samples had the highest pore volumes for the larger pore sizes. The $25 \%$ larger surface area of the ALEW pretreated samples was remarkable, even after considering the higher pore volume for the larger than $2 \mathrm{~nm}$ pores. This larger surface area was probably because of the high lignin content, since most of the lignin micropores were smaller than $0.6 \mathrm{~nm}$ [34].

Table 4. Effects of the pretreatment conditions on the surface areas, average pore sizes, and pore volumes of the critical point drying (CPD) Eucalyptus samples.

\begin{tabular}{cccc}
\hline Pretreatment & Surface Area $\left(\mathbf{m}^{2} / \mathbf{g}\right)$ & Average Pore Diameter $(\AA)$ & Total Pore Volume $\left(\mathbf{c m}^{3} / \mathbf{g}\right)$ \\
\hline Untreated $^{2}$ & 0.8 & 34.1 & 0.007 \\
$\mathrm{ALEW}^{1}$ & 161.5 & 61.7 & 0.249 \\
$\mathrm{DA}^{2}$ & 58.5 & 70.6 & 0.103 \\
$\mathrm{NaOH}-$ steam $^{3}$ & 129.9 & 62.1 & 0.202 \\
\hline
\end{tabular}

${ }^{1}$ Pretreated by alkali electrolyzed water (ALEW) at $180{ }^{\circ} \mathrm{C}$ for $1 \mathrm{~h} .{ }^{2}$ Pretreated by $1 \% \mathrm{H}_{2} \mathrm{SO}_{4}$ at $121{ }^{\circ} \mathrm{C}$ for $2 \mathrm{~h}$.

${ }^{3}$ Pretreated by steam at $160{ }^{\circ} \mathrm{C}$ for $12 \mathrm{~min}$ after $3 \% \mathrm{NaOH}$ soaking for $12 \mathrm{~h}$. DA-dilute acid.

Table 5. Effects of pretreatment conditions on micropore volumes of the Eucalyptus samples.

\begin{tabular}{ccccc}
\hline \multirow{2}{*}{ Pretreatment } & \multicolumn{4}{c}{ Pore Diameter (nm) } \\
\cline { 2 - 5 } & $\boldsymbol{P}_{\boldsymbol{d}}<\mathbf{2}$ & $\mathbf{2}<\boldsymbol{P}_{\boldsymbol{d}}<\mathbf{5}$ & $\mathbf{5}<\boldsymbol{P}_{\boldsymbol{d}}$ & Total \\
\hline $\mathrm{ALEW}$ & 0.019 & 0.08 & $0.15(60 \%) *$ & 0.249 \\
$1 \% \mathrm{H}_{2} \mathrm{SO}_{4}$ & 0.003 & 0.03 & $0.07(68 \%)$ & 0.103 \\
$\mathrm{NaOH}-$ steam & 0.022 & 0.06 & $0.12(59 \%)$ & 0.202 \\
\hline \multicolumn{5}{c}{ * Pore volume fraction. }
\end{tabular}

\section{Conclusions}

Critical point drying was shown to effectively prevent cellulosic pore collapse upon drying, and hence enabled the direct determination of the specific surface area and pore size distribution for pretreated the Eucalyptus samples using the BET method. Comparing hydrogen bonds for the various drying methods, the reformation of hydrogen bonds upon drying is mainly responsible for pore collapse. Thus, hydrogen bond reformation was successfully prevented in CPD by replacing the water with liquid $\mathrm{CO}_{2}$ (a non-polar solvent) before drying.

The measurement technology that was developed in this study will provide more detailed quantitative data on the surface area and pore size distribution of the water-swollen biomass.

The surface areas of the CPD Eucalyptus samples were $58-161 \mathrm{~m}^{2} / \mathrm{g}$, comparable to those that were determined by the indirect measuring methods; whereas the sulfuric acid pretreatment yielded a considerably smaller surface area with a larger average pore diameter, the ALEW pretreatment 
produced the highest surface area, and the $\mathrm{NaOH}$-steam pretreatment produced a somewhat smaller surface area.

Author Contributions: K.-R.H. and J.-S.L. conceived and designed the experiments; J.-Y.P. and J.-P.L. performed the experiments; K.-Y.K. and J.-S.K. analyzed the data; and K.-Y.K. and J.-S.L. wrote the paper.

Acknowledgments: This work was supported by International Collaborative R\&D grant (No. 20138520091130) of the Korea Institute of Energy Technology Evaluation and Planning (KETEP) funded by the Korea Government Ministry of Trade, Industry and Energy. This study was also supported by the research program of Dongguk University, 2017 (S-2017-G0001-00046).

Conflicts of Interest: The authors declare no conflicts of interest.

\section{References}

1. Zhao, X.; Zhang, L.; Liu, D. Biomass recalcitrance. Part 1: The chemical compositions and physical structures affecting the enzymatic hydrolysis of lignocellulose. Biofuels Bioprod. Biorefin. 2012, 6, 465-482. [CrossRef]

2. Mood, S.H.; Golfeshan, A.H.; Tabatabaei, M.; Jouzani, G.S.; Najafi, G.H.; Gholami, M.; Ardjmand, M. Lignocellulosic biomass to bioethanol, a comprehensive review with a focus on pretreatment. Renew. Sustain. Energy Rev. 2013, 27, 77-93. [CrossRef]

3. Meng, X.; Ragauskas, A.J. Recent advances in understanding the role of cellulose accessibility in enzymatic hydrolysis of lignocellulosic substrates. Curr. Opin. Biotechnol. 2014, 27, 150-158. [CrossRef] [PubMed]

4. Grethlein, H.E. The effect of pore size distribution on the rate of enzymatic hydrolysis of cellulosic substrates. Nat. Biotechnol. 1985, 3, 155-160. [CrossRef]

5. Stone, J.E.; Scallan, A.M. A structural model of the cell wall of water-swollen wood pulp fibers based on their accessibility to macromolecules. Cellul. Chem. Technol. 1968, 2, 321-342.

6. Gama, F.M.; Teixeira, J.A.; Mota, M. Cellulose morphology and enzymatic reactivity: A modified solute exclusion technique. Biotechnol. Bioeng. 1994, 43, 381-387. [CrossRef] [PubMed]

7. Huang, R.; Su, R.; Qi, W.; He, Z. Understanding the key factors for enzymatic conversion of pretreated lignocellulose by partial least square analysis. Biotechnol. Prog. 2010, 26, 384-392. [CrossRef] [PubMed]

8. Wang, W.; Liu, P.; Zhang, M.; Hu, J.; Xing, F. The pore structure of phosphoaluminate cement. J. Compos. Mater. 2012, 2, 104-112. [CrossRef]

9. Hong, J.; Ye, X.; Zhang, Y.H. Quantitative determination of cellulose accessibility to cellulase based on adsorption of a nonhydrolytic fusion protein containing CBM and GFP with its applications. Langmuir 2007, 23, 12535-12540. [CrossRef] [PubMed]

10. Del Rio, L.F.; Chandra, R.P.; Saddler, J.N. The effects of increasing swelling and anionic charges on the enzymatic hydrolysis of organosolv-pretreated softwoods at low enzyme loadings. Biotechnol. Bioeng. 2011, 108, 1549-1558. [CrossRef] [PubMed]

11. Wiman, M.; Dienes, D.; Hansen, M.A.T.; van der Meulen, T.; Zacchi, G.; Lidén, G. Cellulose accessibility determines the rate of enzymatic hydrolysis of steam-pretreated spruce. Bioresour. Technol. 2012, 126, 208-215. [CrossRef] [PubMed]

12. Luo, X.; Zhu, J.Y. Effects of drying-induced fiber hornification on enzymatic saccharification of lignocelluloses. Enzyme Microb. Technol. 2011, 48, 92-99. [CrossRef] [PubMed]

13. Foston, M.; Ragauskas, A.J. Changes in the structure of the cellulose fiber wall during dilute acid pretreatment in Populus studied by ${ }^{1} \mathrm{H}$ and ${ }^{2} \mathrm{H}$ NMR. Energy Fuels 2010, 24, 5677-5685. [CrossRef]

14. Meng, X.; Foston, M.; Leisen, J.; DeMartini, J.; Wyman, C.E.; Ragauskas, A.J. Determination of porosity of lignocellulosic biomass before and after pretreatment by using Simons' stain and NMR techniques. Bioresour. Technol. 2013, 144, 467-476. [CrossRef] [PubMed]

15. Thompson, D.N.; Chen, H.-C.; Grethlein, H.E. Comparison of pretreatment methods on the basis of available surface area. Bioresour. Technol. 1992, 39, 155-163. [CrossRef]

16. Seo, D.-J.; Fujita, H.; Sakoda, A. Structural changes of lignocelluloses by a nonionic surfactant, Tween 20, and their effects on cellulase adsorption and saccharification. Bioresour. Technol. 2011, 102, 9605-9612. [CrossRef] [PubMed]

17. Esteghlalian, A.R.; Bilodeau, M.; Mansfield, S.D.; Saddler, J.N. Do enzymatic hydrolyzability and Simons' stain reflect the changes in the accessibility of lignocellulosic substrates to cellulase enzymes? Biotechnol. Prog. 2001, 17, 1049-1054. [CrossRef] [PubMed] 
18. Allen, T. Surface area and pore size determination. In Particle Size Measurement, 5th ed.; Allen, T., Ed.; Springer: London, UK, 1997; Volume 2, pp. 44-108, ISBN 978-0-412-75330-5.

19. Guo, J.; Catchmark, J.M. Surface area and porosity of acid hydrolyzed cellulose nanowhiskers and cellulose produced by Gluconacetobacter xylinus. Carbohydr. Polym. 2012, 87, 1026-1037. [CrossRef]

20. Koo, B.-W.; Min, B.-C.; Gwak, K.-S.; Lee, S.-M.; Choi, J.-W.; Yeo, H.; Choi, I.-G. Structural changes in lignin during organosolv pretreatment of Liriodendron tulipifera and the effect on enzymatic hydrolysis. Biomass Bioenerg. 2012, 42, 24-32. [CrossRef]

21. Park, S.; Venditti, R.A.; Jameel, H.; Pawlak, J.J. Changes in pore size distribution during the drying of cellulose fibers as measured by differential scanning calorimetry. Carbohydr. Polym. 2006, 66, 97-103. [CrossRef]

22. Choi, W.-I.; Park, J.-Y.; Lee, J.-P.; Oh, Y.-K.; Park, Y.C.; Kim, J.S.; Park, J.M.; Kim, C.H.; Lee, J.-S. Optimization of $\mathrm{NaOH}$-catalyzed steam pretreatment of empty fruit bunch. Biotechnol. Biofuels 2013, 6, 170. [CrossRef] [PubMed]

23. Barrett, E.P.; Joyner, L.G.; Halenda, P.P. The determination of pore volume and area distributions in porous substances. I. Computations from nitrogen isotherms. J. Am. Chem. Soc. 1951, 73, 373-380. [CrossRef]

24. Sing, K.S.W.; Everett, D.H.; Haul, R.A.W.; Moscou, L.; Pierotti, R.A.; Rouquérol, J.; Siemieniewska, T. Reporting physisorption data for gas/solid systems with special reference to the determination of surface area and porosity. Pure Appl. Chem. 1985, 57, 603-619. [CrossRef]

25. Mason, G. The effect of pore space connectivity on the hysteresis of capillary condensation in adsorption-desorption isotherms. J. Colloid Interface Sci. 1982, 88, 36-46. [CrossRef]

26. Thommes, M.; Smarsly, B.; Groenewolt, M.; Ravikovitch, P.I.; Neimark, A.V. Adsorption hysteresis of nitrogen and argon in pore networks and characterization of novel micro- and mesoporous silicas. Langmuir 2006, 22, 756-764. [CrossRef] [PubMed]

27. Mishra, D.K.; Samad, S.K.; Varma, A.K.; Mendhe, V.A. Pore geometrical complexity and fractal facets of Permian shales and coals from Auranga Basin, Jharkhand, India. J. Nat. Gas Sci. Eng. 2018, 52, $25-43$. [CrossRef]

28. Suleimenova, A.; Bake, K.D.; Ozkan, A.; Valenza, J.J., II; Kleinberg, R.L.; Burnham, A.K.; Ferralis, N.; Pomerantz, A.E. Acid demineralization with critical point drying: A method for kerogen isolation that preserves microstructure. Fuel 2014, 135, 492-497. [CrossRef]

29. Nordestgaard, B.G.; Rostgaard, J. Critical-point drying versus freeze drying for scanning electron microscopy: A quantitative and qualitative study on isolated hepatocytes. J. Microsc. 1985, 137, 189-207. [CrossRef] [PubMed]

30. Jie, X.; Cao, Y.; Qin, J.J.; Liu, J.; Yuan, Q. Influence of drying method on morphology and properties of asymmetric cellulose hollow fiber membrane. J. Membr. Sci. 2005, 246, 157-165. [CrossRef]

31. Liu, W.; Hou, Y.; Wu, W.; Niu, M.; Wang, W. Pretreatment of wheat straw using $\mathrm{SO}_{2}$ dissolved in hot water. Bioresour. Technol. 2012, 124, 306-310. [CrossRef] [PubMed]

32. Kawamoto, H.; Ueno, Y.; Saka, S. Thermal reactivities of non-reducing sugars in polyether-Role of intermolecular hydrogen bonding in pyrolysis. J. Anal. Appl. Pyrolysis 2013, 103, 287-292. [CrossRef]

33. Zhu, Z.; Sathitsuksanoh, N.; Vinzant, T.; Schell, D.J.; McMillan, J.D.; Zhang, Y.-H.P. Comparative study of corn stover pretreated by dilute acid and cellulose solvent-based lignocellulose fractionation: Enzymatic hydrolysis, supramolecular structure, and substrate accessibility. Biotechnol. Bioeng. 2009, 103, 715-724. [CrossRef] [PubMed]

34. Nakatani, T.; Ishimaru, Y.; Iida, I.; Furuta, Y. Micropore structure of wood: Change in micropore structure accompanied by delignification. J. Wood Sci. 2008, 54, 252-255. [CrossRef]

(C) 2018 by the authors. Licensee MDPI, Basel, Switzerland. This article is an open access article distributed under the terms and conditions of the Creative Commons Attribution (CC BY) license (http:// creativecommons.org/licenses/by/4.0/). 